\title{
Efficiency of Rural Banks: The Case of India
}

\author{
Professor Dilip Khankhoje \\ National Institute of Bank Management, Pune, India
}

\author{
Dr Milind Sathye (Corresponding author) \\ School of Business and Government \\ University of Canberra \\ Bruce ACT 2617, Australia
}

Tel: 61-2-6201-5489 Fax: 61-2-6201-5238Ｅ-mail: Milind.Sathye@.canberra.edu.au

\begin{abstract}
The objective of this paper is to investigate whether the restructuring of regional rural banks in India -undertaken in 1993-94 - has helped improve their production efficiency. Several committees have emphasized the need to improve the efficiency of these banks which are an important arm of the rural credit system in India. Improved production efficiency in provision of services would mean lower cost and financially sustainable operations. Production efficiency has been measured using a non-parametric technique of Data Envelopment Analysis (DEA). To measure efficiency most directly, interest income and non-interest income were used as outputs and interest expenses and non-interest expenses were used as inputs. Efficiency scores were calculated for the years 1990 to 2002. Thereafter these scores were compared for before and after the restructuring year (1993-94). The study finds that efficiency of rural banks has significantly improved after restructuring. It seems the policy of the Government of India to restructure these banks has shown positive results and the study recommends its continuance.
\end{abstract}

JDE classification: E5, G2, N2, R3

Keywords: Rural Bank efficiency; DEA analysis, Indian banks

\section{Introduction}

The objective of this study is to measure the variation in the performance (in terms of productive efficiency) of Regional Rural Banks (RRBs) in India and to assess if the efficiency of these institutions has increased post-restructuring (in 1993-94). Studies during the later half of the 1990s indicated that 'the reforms ...... have done little to increase the internal efficiency of the RRBs' (see Gupta 1998, Reserve Bank of India (RBI) 1997 for example). These were not academic studies and did not use rigorous framework and recent efficiency measurement techniques like the Data Envelopment Analysis. The question therefore remains whether the programme of restructuring launched by the Government of India resulted in efficiency improvements of these banks which are an important arm of the rural credit system in India. We fill this gap in the literature.

A study of the efficiency of the rural banks is particularly important in the Indian context. 'Efficiency linkages to long-term viability are especially critical to rural banks since these banks play a vital role in influencing regional flows of funds' (Ellinger, 1994, p. 653). These banks are under public ownership and were created in 1975 exclusively to meet the credit needs of the rural poor. There was a feeling that though commercial banks had branches in rural areas these were used mainly to mobilise resources which were then deployed in urban areas. The idea behind setting up the RRBs was that the resources mobilised in rural areas would be used for lending in rural areas. In so doing, however, these banks were required to be run on commercial principles. 'The working group ....recommended for setting up of State sponsored region based rural oriented commercial banks (emphasis added), ........with the modernised outlook of commercial banks (emphasis added). In a sense, it was an experiment to hybridise commercial banking culture with a rural ethos' (Loksabha, 2004). Their business operations are restricted to a particular geographical jurisdiction, that is, one or two districts and were meant to be low cost institutions. There were also subsidies involved as the chief executive/s was seconded by one of the nationalised banks sponsoring them which contributed to its capital along with the Government of India (GOI), and State Government. The Board of the banks consists of representatives from all these owners. The banks are subject to prudential supervision of the Reserve Bank of India. Their efficient operation was crucial to achieve one of the major policy objectives of the Government of India, viz., to help in eradication of rural 
poverty. As the banks were operating under several restrictions, improving efficiency is an important strategy to reduce costs and generate surplus - something that is necessary for their long-term sustainability. The Narsimhan Committee (1998) emphasized that 'While discharging their functions as purveyors of rural credit and mobilisers of rural savings, RRBs should not ignore the importance of financial viability and operational efficiency. The productivity, profitability and solvency of the RRBs must be maintained and sustained to enable them to function as an effective and efficient institution of rural credit' (RBI, 2004).

Interestingly, despite their importance in the Indian context, these banks have not been the subject of academic studies though the commercial banks that coexist with them in rural credit markets have been studied by several researchers. Efficiency study of rural banks would be helpful in locating sources of inefficiencies and enable all the stakeholders to take a fresh look at their functioning and initiate suitable strategic measures given their importance in achieving national objective of alleviation of rural poverty. There is growing interest in the Indian economy as the economy continues to rapidly progress like China to become a major economic power as evidenced by the rise in number of foreign banks to 29 and their branches to 258 (2006). In the late 1990s, it was reported by the media that Morgan Stanley evinced interest in acquiring the RRBs. Several foreign banks who are interested in expanding in rural credit market in India for diversification of risk may find acquiring the RRBs as a possible option to consider and would be interested in knowing their efficiency. The paper would also help those who are interested in assessing the efficiency of similar institutions in other countries.

The paper is organized as follows. A brief review of the current state of the Indian rural banking sector is provided in section 2. In section 3 data and methodology are discussed. Section 4 presents the results and section 5 concludes this paper.

\section{An overview of the Indian rural banking sector}

The rural credit market in India consists of both formal and informal financial institutions and agencies that meet the credit needs of the rural population. For the purpose of classification of bank branches, the Reserve Bank defines rural area as a place with a population of less than 10,000. RRBs compete with the commercial banks in rural credit market of India. RRBs give loans for agriculture and rural development while commercial banks also serve needs of commerce and industry in rural areas.

Table 1 presents the rural credit delivery set up (branches of formal credit institutions) in India as of 30 June

As can be seen from the above Table, RRBs occupy an important position in the rural credit market of India. The rationale for establishment of the RRB was to 'combine the local feel and familiarity with rural problems, which the cooperatives possess, and the degree of business organization, ability to mobilise deposits, access to central money market and modernised outlook, which the commercial banks have' (Narsimham Committee, 1975, p23). Though the RRBs were intended to be low-cost institutions, a land mark court ruling in the year 1993 granted the staff of RRBs equal pay and perquisites as were available to the staff of commercial banks. This 'added to the bank's already escalating costs' (Bhatt and Thorat, p13) and questions about improving their efficiency through restructuring began to be asked. In 1993-94 the GOI introduced a program for restructuring of these banks to make them operationally efficient and financially self sustainable. Several measures were initiated. To enhance financial viability of these banks, a new set of prudential accounting norms of income recognition, asset classification, provisioning, and capital adequacy were implemented. Banks were also required to make full provisioning for bulk of their non-performing assets. Furthermore, they were permitted to lend to non-target group borrowers up to 60 per cent of new loans beginning in 1993-94. Permission was also granted to introduce new services, such as loans for consumer durables. As such the year 1993-94 marks a break and has been used as a cut off year for examining the efficiency of the rural banks.

In the following tables we present some important banking indicators of RRBs in India.

As against the total loans outstanding by the RRBs of Rs 261 billion in 2004, the commercial banks loans outstanding were Rs 11.5 trillion. Data on loans outstanding of commercial banks in rural areas is not separately available to make the comparison with the RRBs. The net non performing assets of RRBs as proportion of net advances in 2004 was $5.3 \%$ as against $7.2 \%$ of all commercial banks. Since the early 1990s, the Government of India has implemented many banking sector reforms. These include lowering of the cash reserve ratio from 15 per cent (1993-94) to 8.5 percent (July 2000), lowering of the statutory liquidity ratio from 38.5 per cent (1992-93) to 28.2 per cent (1995-96), a gradual deregulation of interest rates on deposits and lending, introduction of prudential norms in line with the international standards and the like. A system of flexible exchange rates on current account has been adopted. The Committee on the Financial System, appointed by the Government of India in 1991, identified directed investment and credit programmes as the two main sources of declining efficiency, productivity and profitability among commercial banks. Consequently, the percentage of priority sector advances has declined to 37 per cent (1998) and percentage of rural branches network has come down to 42 per cent. The restriction on RRBs to confine their advances exclusively to the weaker sections of rural society were removed. Certain limitations on the avenues open to them for making their 
investments were also dispensed with. These and similar other policy initiatives indicate the desire to make Indian banking more competitive by establishing a level playing field among the three groups of banks. As more than a decade has now elapsed since the initiation of the banking sector reforms, it is appropriate to take stock of the production efficiency of rural banks in India.

\section{Literature on banking efficiency in India}

It is usual to measure the performance of banks using financial ratios. Yeh (1996) notes that the major demerit of this approach is its reliance on benchmark ratios. These benchmarks could be arbitrary and may mislead an analyst. Further, Sherman and Gold (1985) note that financial ratios don't capture the long-term performance, and aggregate many aspects of performance such as operations, marketing and financing. In recent years, there is a trend towards measuring bank performance using one of the frontier analysis methods. In frontier analysis, the institutions that perform better relative to a particular standard are separated from those that perform poorly. Such separation is done either by applying a non-parametric or parametric frontier analysis to firms within the financial services industry. The parametric approach includes stochastic frontier analysis, the free disposal hull, thick frontier and the Distribution Free Approaches (DFA), while the non-parametric approach is Data Envelopment Analysis (DEA) (Molyneux et al. 1996). In this paper, the DEA approach has been used. This approach has been used since "recent research has suggested that the kind of mathematical programming procedure used by DEA for efficient frontier estimation is comparatively robust" (Seiford and Thrall, 1990). Furthermore, after Charnes, Cooper and Rhodes (1978) who coined the term DEA, a 'large number of papers have extended and applied the DEA methodology' (Coelli, 1996).

There are many studies that have measured the efficiency of banks the world over, however, very few studies have evaluated the performance of Indian banks. Tyagarajan (1975), Rangarajan and Mampilly (1972), and Subramanyam (1993) have examined various issues relating to the performance of Indian commercial banks, but none of these studies have examined the efficiency of rural bank service provision in India. Some recent studies did measure the efficiency' dimension in service provision of Indian commercial banks but they suffer from certain limitations as indicated in this paper. Sathye (2003) studied the efficiency of Indian commercial banks for the year 1997-98. The results are shown in Table 3.

The efficiency of rural banks is being studied for the first time to the author's knowledge.

\section{Methodology}

The present study uses the latest available published data for the years 1990-2002 compiled from Financial Statement of Regional Rural Banks and Statistics on Regional Rural Banks compiled by the National Bank for Agriculture and Rural Development for the relevant years. As per this database, in the years 1990-2002, there were 196 regional rural banks (RRBs) in India. We take 1993-94 as the cut off year to compare efficiency pre and post restructuring.

The first step in the analysis is the measurement of bank's productive efficiency. Following Bhattacharya et al. (1997), performance has been associated with technical efficiency (hereafter refereed to as 'efficiency'). It is the ability to transform multiple resources into multiple financial services. The efficiency has been calculated using variable returns to scale (VRS) input oriented model of the DEA methodology. To measure efficiency as directly as possible, that is, management's success in controlling costs and generating revenues (that is, x-efficiencies), two input and two output variables, namely, interest expenses, non-interest expenses (inputs) and net interest income and non-interest income (outputs) have been used. These variables capture all the activities undertaken by the bank and have been used in prior studies (see Avkiran, 1999 for example). Interest income captures the loan and investment activities undertaken by the bank, non-interest income captures other activities (mainly fee based) of the bank. Interest expenses capture the efficiency (low cost) in raising funds and non-interest expenses capture the operating

The choice of inputs and outputs in DEA is a matter of long standing debate among researchers. Two approaches exist. One is called the production approach while the other an intermediation approach. The production approach uses number of accounts of deposits or loans as inputs and outputs respectively. This approach assumes that banks produce loans and other financial services. The intermediation approach on the other hand considers banks as financial intermediaries and uses volume of deposits, loans and other variables as inputs and outputs. Most of the DEA studies follow an intermediation approach. Within the intermediation approach, the exact set of inputs and outputs used depends largely on data availability. As already stated DEA is sensitive to the choice of input-output variables. This is strength of the technique, since it reveals which of the input-output variables need to be closely monitored by bank management to improve efficiency.

\section{Data Envelopment Analysis}

DEA is a linear programming technique initially developed by Charnes, Cooper and Rhodes (1978) to evaluate the efficiency of public sector non-profit organisations. Sherman and Gold (1985) were the first to apply DEA to banking. DEA calculates the relative efficiency scores of various Decision-Making Units (DMUs) in the particular sample. The DMUs could be banks or branches of banks. The DEA measure compares each of the banks/branches in that sample 
with the best practice in the sample. It tells the user which of the DMUs in the sample are efficient and which are not. The ability of the DEA to identify possible peers or role models as well as simple efficiency scores gives it an edge over other methods. As an efficient frontier technique, DEA identifies the inefficiency in a particular DMU by comparing it to similar DMUs regarded as efficient, rather than trying to associate a DMU's performance with statistical averages that may not be applicable to that DMU.

Methodologically, the characteristics of DEA can be described through the original model developed by Charnes, Cooper and Rhodes. Consider $\mathrm{N}$ units (each is called a Decision Making Unit, DMU) that convert $I$ inputs into $J$ outputs, where $I$ can be larger, equal or smaller than $J$. To measure efficiency of this converting process for a DMU, Charnes et al. propose the use of the maximum of a ratio of weighted outputs to weighted inputs for that unit, subject to the condition that the similar ratios for all other DMUs be less than or equal to one. That is,

$\operatorname{Max} e^{0}=\frac{\sum_{j=1}^{J} u_{j}^{o} y_{j}^{o}}{\sum_{i=1}^{I} v_{i}^{o} x_{i}^{o}}$

Subject to

$\frac{\sum_{j=1}^{J} u_{j}^{o} y_{j}^{n}}{\sum_{i=1}^{I} v_{i}^{o} x_{i}^{n}} \leq 1 ; \quad n=1, \ldots . . N$,
$v_{i}^{o}, u_{j}^{o} \geq 0 ; \quad i=1, \ldots ., ; \quad j=1, \ldots \ldots J$.

where $y_{j}^{n}, x_{j}^{n} \quad$ are positive known outputs and inputs of the $\mathrm{n}^{\text {th }}$ DMU and $v_{i}^{o}, u_{j}^{o}$ are the variable weights to be determined by solving problem (1). The DMU being measured is indicated by the index 0 , which is refereed to as the base DMU. The maximum of the objective function $e^{o}$ given by problem (1) is the DEA efficiency score assigned to $\mathrm{DMU}^{0}{ }^{0}$. Since every DMU can be DMU ${ }^{0}$, this optimisation problem is well-defined for every DMU. If the efficiency score $e^{o}=1, \mathrm{DMU}^{0}$, satisfies the necessary condition to be DEA efficient; otherwise it is DEA inefficient.

It is difficult to solve problem (1) as stated, because the objective function is non-linear and fractional. Charnes et al, however, transformed the above nonlinear programming problem into a linear one as follows,

$\operatorname{Maxh}^{o}=\sum_{j=1}^{J} u_{j}^{o} y_{j}^{o}$

Subject to

$\sum_{i=1}^{I} v_{i}^{o} x_{i}^{o}=1, \sum_{j=1}^{j} u_{j}^{o} y_{j}^{n}-\sum_{i=1}^{I} v_{i}^{o} x_{i}^{n} \leq 0 ; \quad \mathrm{n}=1, \ldots \ldots . N$,

$v_{i}^{o} \geq \mathcal{E}, \quad u_{j}^{o} \geq \mathcal{\varepsilon}, \quad \mathrm{i}=1, \ldots . . I, \quad \mathrm{j}=1, \ldots \ldots, J$.

The variables defined in problem (2) are the same as those defined in problem (1). An arbitrarily small positive number, $\mathcal{E}$ is introduced in problem (2) to ensure that all of the known inputs and outputs have positive weight values and that the optimal objective function of the dual problem to problem (2) is not affected by the values assigned to the dual slack variables in computing the DEA efficiency score for each DMU. The condition $h^{\circ}=1$ ensures that the base $\mathrm{DMU}^{\circ}$ is DEA efficient; otherwise it is DEA inefficient, with respect to all other DMUs in the test. A complete DEA model involves the solution of $N$ such problems, each for a base DMU, yielding $N$ different $\left(v_{i}^{n}, u_{j}^{n}\right)$ weight sets. In each program, the constraints are held constant while the ratio to be maximized is changed.

DEA modelling allows the analyst to select inputs and outputs in accordance with a managerial focus. This is an advantage of DEA since it opens the door to what-if analysis. Furthermore, the technique works with variables of different units without the need for standardisation (e.g. dollars, number of transactions, or number of staff). Fried and Lovell (1994) have given a list of questions that DEA can help to answer.

However, DEA has some limitations. Those DMUs indicated as efficient are only efficient in relation to others in the sample. It may be possible for a unit outside the sample to achieve a higher efficiency than the best practice DMU in the 
sample. Knowing which efficient banks are most comparable to the inefficient banks enables the analyst to develop an understanding of the nature of inefficiencies and re-allocate scarce resources to improve productivity. This feature of DEA is clearly a useful decision-making tool in benchmarking. As a matter of sound managerial practice, profitability measures should be compared with DEA results and significant disagreements investigated. The DEA technique has been used in efficiency analysis of banks (rather than branches); some recent examples are Yue (1992), Berg et al. (1993), Favero and Papi (1995), Wheelock and Wilson (1995), Miller and Noulas (1996), Resti (1997) and Sathye (2001).

\section{Results}

Tables 4 (a) and (b) present descriptive statistics of inputs and outputs used in the model:

Tables 4 (c) and (d) provide the descriptive statistics of RRB efficiency scores calculated for pre and post restructuring years. The mean efficiency score of the RRBs shows an increase in post-restructuring years as Table 4 (a) and Table 4 (b) demonstrate. The efficiency scores of each of the banks for each the years under study are also available on request from authors (not reported here as the Table will be unwieldy). The mean efficiency scores of each of the RRBs for each of the years under study are shown in Appendix 1.

Next we compare whether the post-restructuring efficiency is significantly different from the pre-restructuring efficiency of these banks in order to test the hypothesis whether restructuring helped in efficiency improvement. ANOVA test results are shown in Table 5.

The results from Tables 4 and 5 show that there is strong evidence that mean efficiency of the RRBs before introduction of restructuring significantly differs from the mean efficiency of the RRBs post restructuring. Both the standard ANOVA and the Welch adjusted ANOVA statistics are significant with probability values of zero.

We conclude that restructuring has in fact considerably improved efficiency of the RRBs and that the government may like to continue with the policy.

The scores computed need some explanation. As already stated DEA is a flexible technique and produces efficiency scores that are different when alternative sets of inputs and outputs are used. Though the comparison of efficiency scores of RRBs with those of the commercial banks may not be appropriate since the latter have a presence nation wide and also in metropolitan and urban areas and not necessarily in rural areas, these are quoted here as have been estimated in other studies (see Table 3 above). However, these are available for only one year 1997-98. The mean efficiency of 196 RRBs in the year 1997-98 was 0.60. The RRBs were on average less efficient than commercial banks in the year 1997-98. This need not come as a surprise since these institutions suffer from many disadvantages as compared to commercial banks as already indicated in this paper. The redeeming feature is that these institutions have shown improved performance in recent years and restructuring measures seem to have a positive impact on the working in these institutions - an important arm of the Indian rural credit delivery set up. The GOI may like to consider the merger of these banks to bring about scale efficiency improvements. Bigger size banks would be able to afford new technologies and would also be able to thereby improve technical efficiency. Sardesai Committee (2005) also supports merger of these banks. The Sardesai committee held that 'to improve the operational viability of RRBs and take advantage of the economies of scale, the route of merger/amalgamation of RRBs may be considered taking into account the views of the various stakeholders' (Misra, 2006, p. 94).

\section{Conclusion}

Using published data, we calculated the production efficiency score of regional rural banks in India for the years 1990 to 2002. The scores were calculated using the non-parametric technique of Data Envelopment Analysis. As a major restructuring of these banks occurred in the year 1993-94, the mean efficiency scores of pre-restructuring and post restructuring years were compared using ANOVA to test whether restructuring has resulted in improving efficiency of these banks. The study shows that the mean efficiency score of RRBs has shown a significant increase. This study recommends that the existing policy of bringing down non-performing assets as well as curtailing the establishment expenditure through voluntary retirement scheme for bank staff and rationalization of rural branches are steps in the right direction that could help these banks improve efficiency further over a period of time. The findings may be of use to rural banking institutions and policy makers in developing countries and to academics researchers in the area of banking efficiency.

\section{References}

Aly, A. I., Seiford, L. M. 1993. The mathematical programming approach to efficiency analysis in: Fried, H. O., Lovell, C. A. K., Schmidt, S. S., (Eds) The measurement of Productive Efficiency; Techniques and Applications, Oxford University Press, U K, 120-159.

Avkiran, N. K. 1999. The evidence of efficiency gains: The role of mergers and the benefits to the public. Journal of Banking and Finance 23, 991-1013. 
Banker, R. D., Charnes, A., Cooper, W. W., Swarts, J., Thomas, D. A. 1989. An introduction to Data Envelopment Analysis with some of its models and their uses, in Chan, J. L., Patton J. M. (Eds.) Research in Governmental and Non Profit Aaccounting, Vol._5. Jai Press, Greenwich CN, 125-63.

Bauer, P. W. 1990. Recent developments in the econometric estimation of frontiers. Journal of Econometrics 46, 39-56.

Berg, S. A. Forsund, F. R., Hjalmarsson, L. and Souminen, M. 1993. "Banking efficiency in Nordic countries", Journal of Banking and Finance, Vol. 17, 371-88.

Berger, A. N., Humphrey, D.B. 1997. "Efficiency of financial institutions: International survey and directions for future research", European Journal of Operations Research (Special Issue) http://papers.ssrn.com/paper.taf? ABSTRACT_ID=2140

Bery, S. 1996. "India: Commercial Bank Reform" in Financial Sector Reforms, Economic Growth and Stability: Experiences in Selected Asian and Latin American Countries (Ed) Faruqi, Shakil. EDI Seminar Series, The World Bank, Washington, D. C.

Bhattacharya, A., Lovell, C.A.K., and Sahay, P. 1997. "The impact of liberalization on the productive efficiency of Indian commercial banks", European Journal of Operational Research, 98, 332-345.

Bhatt, N and Y.S. P Thorat. 2001. India's Rural Banks: The institutional dimension of reforms, Journal of Microfinance, v3 (1).

Charnes, A., Cooper, W.W., Rhodes, E. 1978. Measuring efficiency of decision making units. European Journal of Operations Research 2, 429-44.

Chatterjee, G. 1997. “ Scale Economies in Banking: Indian Experience in Deregulated Era”, RBI Occasional Papers, Vol. 18 No. 1, 25-59.

Coelli, T. 1996. A Guide to DEAP Version 2.1, A Data Envelopment Analysis (Computer) Program. CEPA Working Paper 96/08.

Ellinger, P. (1994) Potential Gains from Efficiency Analysis of Agricultural Banks American Journal of Agricultural Economics, 76 (3) pp. 652-654.

Favero, C. A. and Papi, L. 1995. "Technical efficiency and scale efficiency in the Italian banking sector: a non-parametric approach"m, Applied Economics, Vol. 27 No. 4, 385-95.

Fried, H. O., Lovell, C. A. K. 1994. Measuring efficiency and evaluating performance. quoted in Data Envelopment Analysis: A technique for measuring the efficiency of government service delivery. Steering Committee for the Review of Commonwealth/state Service Provision. 1997. AGPS, Canberra.

Government of India, Report of the Committee on Rural Banks, (Chairman - M Narsimham), New Delhi, 1975

Gupta, R. V. (1998). Report of the High-level Committee on Agricultural Credit Through Commercial Banks. Reserve Bank of India. Mumbai.

IBA (Indian Banks’ Association). 1999. Performance Highlights of Banks, 1997-98, Indian Banks Association, Mumbai.

Khanna A. 1995. 'South Asian Financial Sector Development' in Financial Sector Development in Asia, (Ed.) S. N. Zahid, Oxford University Press, Oxford.

[Loksabha] Parliament of India (2004) Motion for consideration of 'The Regional Rural Banks (Amendment) Bill, 2004.

http://164.100.24.208/debate14/debtext.asp?slno=2312\&ser=\&smode $=$

Mester, L. J. 1996. “ A study of bank efficiency taking into account risk preferences”, Journal of Banking and Finance, Vol.20 No. 6, 1025-45.

Misra, B. (2006) The Performance of Regional Rural Banks (RRBs) in India:Has Past

Anything to Suggest for Future? Reserve Bank of India Occasional Papers, 27 (1), Reserve Bank of India, Mumbai.

Miller, S. M. and Noulas, A. G. 1996. "The technical efficiency of large bank production", Journal of Banking and Finance, Vol. 20 No. 3, 495-509.

Molyneux, P., Altunbas, Y., Gardener, E. 1996. Efficiency in European Banking. John Wiley Chichester 198.

Rangarajan, C. 1995. 'Inaugural address at the $18^{\text {th }}$ Bank Economists' conference', Reserve Bank of India Bulletin, December, XLIX (12), Reserve Bank of India, Mumbai. 
Rangarajan, C., and Mampilly, P. 1972. "Economies of scale in Indian banking”, in: Technical Studies for Banking Commission Report, Reserve bank of India, Mumbai, 244-268.

Reserve Bank of India. (1997). Report of the expert group on regional rural banks. Reserve Bank of India. New Delhi.

Reserve Bank of India. (2004) Major recommendations of various committees /working groups on Regional Rural Banks.

Available at http://rbidocs.rbi.org.in/rdocs/content/PDFs/78971.pdf accessed on 8 Nov. 2007.

Resti, A. 1997. "Evaluating the cost-efficiency of the Italian banking system:what can be learned from the joint application of parametric and non-parametric techniques', Journal of Banking and Finance, ${ }_{2}$ Vol. 21 No. 2, 221-50.

Narasimhan Committee. 1991. Report of the Committee on the Financial System, Government of India.

RTPB, (Report on Trend and Progress of Banking in India 1995-96), Reserve Bank of India Bulletin 2 March 1997. 34-35.

Saha. A, and T. S. Ravishankar. 2000. Rating of Indian Commercial banks: A DEA approach, European Journal of Operations Research ${ }_{2}$ 124, 187-203.

Sathye, M. 1997. 'Lending Costs, Margins and Financial Viability of Rural Lending Institutions in South Korea' Spellbound Publications, Rohtak, India.

Sathye, M. 2001. "X-efficiency in Australian banking: an empirical investigation", Journal of Banking and Finance, 25, 613-630.

Second Narasimhan Committee. 1997. Committee on Banking Sector Reform, Gazette of India-Extraordinary Notification, Part II, Sec 3 (ii), Ministry of Finance, Government of India.

Seiford, L.M., Thrall, R. M. 1990. Recent developments in DEA. The mathematical programming approach to frontier analysis. Journal of Econometrics_46, 7-38.

Sherman, H. D. and F. Gold. 1985. Bank Branch Operating Efficiency: Evaluation with Data Envelopment Analysis, Journal of Banking and Finance, Vol. 9, \#2, 297-315.

Subrahmanyam, G. 1993. "Productivity growth in India's public sector banks: 1979-89", Journal of Quantitative Economics, 9, 209-223.

Thakur, S. 1990. Two Decades of Indian Banking: The Service Sector Scenario, Chanakya Publications, Delhi.

Tyagarajan, M. 1975. "Expansion of commercial banking. An assessment", Economic and Political Weekly 10, 1819-1824.

Yeh, Q. 1996. "The Application of Data Envelopment Analysis in Conjunction with Financial Ratios for Bank Performance Evaluation', Journal of Operational Research Society, Vol. 47, 980-988.

Yue, P. 1992. Data Envelopment Analysis and Commercial bank performance with Applications to Missourie Banks, Federal Reserve Bank of St Louis Economic Review 2 January/February, 31-45.

Wheelock, D. C. and Wilson, P. W. 1995. "Evaluating the efficiency of commercial banks: does our view of what banks do matter?” Review: Federal Reserve Bank of St Louis, July/August, 39-52.

\section{Notes}

Note 1. Readers interested in the details of the various frontier measurement techniques are encouraged to consult the works of Banker, Charnes, Cooper, Swarts and Thomas (1989), Bauer (1990), and Seiford and Thrall (1990), Aly and Seiford (1993) etc. There are a number of software options for running DEA. This study uses the software (DEAP) developed by Coelli (1996) to calculate the efficiency scores. 
Attachment 1. Mean efficiency scores of Regional Rural Banks the years 1990-2002

\begin{tabular}{|l|l|l|l|}
\hline & CRS & VRS & Scale \\
\hline 1990 & 0734 & 0.753 & 0.976 \\
\hline 1991 & 0.677 & 0.734 & 0.921 \\
\hline 1992 & 0.724 & 0.737 & 0.984 \\
\hline 1993 & 0.666 & 0.691 & 0.963 \\
\hline 1994 & 0.604 & 0.662 & 0.914 \\
\hline 1995 & 0.653 & 0.675 & 0.966 \\
\hline 1996 & 0.587 & 0.612 & 0.955 \\
\hline 1997 & 0.479 & 0.553 & 0.870 \\
\hline 1998 & 0.604 & 0.635 & 0.948 \\
\hline 1999 & 0.680 & 0.713 & 0.958 \\
\hline 2000 & 0.632 & 0.678 & 0.938 \\
\hline 2001 & 0.731 & 0.763 & 0.962 \\
\hline 2002 & 0.726 & 0.755 & 0.963 \\
\hline
\end{tabular}

Table 1. Number of Branches of Banks in rural India (As on June 30)

\begin{tabular}{|l|l|l|l|l|}
\hline & 1990 & 1995 & 2000 & 2004 \\
\hline Commercial banks & 20348 & 18495 & 18472 & 18002 \\
\hline $\begin{array}{l}\text { District Central } \\
\text { Co-operative Banks }\end{array}$ & 10585 & 11653 & 12407 & $12547^{*}$ \\
\hline Regional Rural banks & 14443 & 14509 & 14301 & 14433 \\
\hline
\end{tabular}

Source: Reserve Bank of India, Report on Trend and Progress of Banking in India, and Statistical Tables relating to banks in India (various years) * for 2003.

Table 2. Key banking indicators of RRBs

\begin{tabular}{|l|l|l|l|l|}
\hline Year & Number & Branches & Deposits (Rs. Billion) & Advances (Rs. Billion) \\
\hline 1990 & 196 & 14443 & 41.51 & 35.54 \\
\hline 1995 & 196 & 14509 & 111.50 & 62.91 \\
\hline 2000 & 196 & 14301 & 322.04 & 131.84 \\
\hline 2003 & 196 & 14433 & 500.98 & 221.58 \\
\hline 2004 & 196 & 14446 & 563.50 & 261.14 \\
\hline
\end{tabular}

(Source: Table 2. National Bank for Agriculture and Rural Development, 2004, Regional Rural Banks Key Statistics, National Bank for Agriculture and Rural Development. Mumbai. Table 2 (b) and (c): calculated by the authors).

Table 3. Efficiency scores of commercial banks 1997-98

\begin{tabular}{|l|l|l|}
\hline & N & Mean \\
\hline Public sector & 27 & 0.89 \\
\hline Private sector & 33 & 0.78 \\
\hline Foreign banks & 34 & 0.84 \\
\hline All banks & 94 & 0.83 \\
\hline
\end{tabular}


Table 4 (a) . Descriptive Statistics of inputs and outputs used in the model: Pre-restructuring years

\begin{tabular}{|l|l|l|l|l|l|l|l|}
\hline $\begin{array}{l}\text { Int. } \\
\text { Income }\end{array}$ & & $\begin{array}{l}\text { Non-int } \\
\text { Income }\end{array}$ & & $\begin{array}{l}\text { Int. } \\
\text { expenses }\end{array}$ & & $\begin{array}{l}\text { Non-int } \\
\text { Exp }\end{array}$ & \\
\hline Mean & 412.292 & Mean & 11.167 & Mean & 238.270 & Mean & 211.462 \\
\hline Median & 230.4 & Median & 5.22 & Median & 166.33 & Median & 153.985 \\
\hline Mode & 12.14 & Mode & 0.9 & Mode & 10.52 & Mode & 95.53 \\
\hline $\begin{array}{l}\text { Standard } \\
\text { Deviation }\end{array}$ & 959.404 & $\begin{array}{l}\text { Standard } \\
\text { Deviation }\end{array}$ & 24.133 & $\begin{array}{l}\text { Standard } \\
\text { Deviation }\end{array}$ & 238.638 & $\begin{array}{l}\text { Standard } \\
\text { Deviation }\end{array}$ & 198.069 \\
\hline Kurtosis & 474.427 & Kurtosis & 110.028 & Kurtosis & 9.325 & Kurtosis & 15.251 \\
\hline Skewness & 19.516 & Skewness & 8.593 & Skewness & 2.469 & Skewness & 2.971 \\
\hline Range & 24078.83 & Range & 419.36 & Range & 2100.99 & Range & 2016.56 \\
\hline Minimum & 2.56 & Minimum & -21.56 & Minimum & 2.54 & Minimum & 4.49 \\
\hline Maximum & 24081.39 & Maximum & 397.8 & Maximum & 2103.53 & Maximum & 2021.05 \\
\hline Count & 784 & Count & 784 & Count & 784 & Count & 784 \\
\hline
\end{tabular}

Table 4 (b) . Descriptive Statistics of inputs and outputs used in the model: Post-restructuring years

\begin{tabular}{|l|l|l|l|l|l|l|l|}
\hline Int. Income & & $\begin{array}{l}\text { Non-int } \\
\text { Income }\end{array}$ & & $\begin{array}{l}\text { Int. } \\
\text { expenses }\end{array}$ & & $\begin{array}{l}\text { Non-int } \\
\text { Exp }\end{array}$ & \\
\hline Mean & 1420.949 & Mean & 83.311 & Mean & 960.568 & Mean & 731.0356 \\
\hline Median & 939.105 & Median & 38.875 & Median & 683.825 & Median & 454.67 \\
\hline Mode & 414.18 & Mode & 46.08 & Mode & 103.04 & Mode & 584.7 \\
\hline $\begin{array}{l}\text { Standard } \\
\text { Deviation }\end{array}$ & 1507.261 & $\begin{array}{l}\text { Standard } \\
\text { Deviation }\end{array}$ & 143.404 & $\begin{array}{l}\text { Standard } \\
\text { Deviation }\end{array}$ & 921.232 & $\begin{array}{l}\text { Standard } \\
\text { Deviation }\end{array}$ & 957.940 \\
\hline Kurtosis & 8.638 & Kurtosis & 67.150 & Kurtosis & 6.586 & Kurtosis & 22.285 \\
\hline Skewness & 2.470 & Skewness & 6.355 & Skewness & 2.208 & Skewness & 4.148 \\
\hline Range & 12448.27 & Range & 2361.68 & Range & 6862.88 & Range & 9061.09 \\
\hline Minimum & 17.64 & Minimum & 0.06 & Minimum & 15.06 & Minimum & -357.37 \\
\hline Maximum & 12465.91 & Maximum & 2361.74 & Maximum & 6877.94 & Maximum & 8703.72 \\
\hline Count & 1764 & Count & 1764 & Count & 1764 & Count & 1764 \\
\hline
\end{tabular}

Table 4 (c) . Descriptive statistics of RRB efficiency: Pre-restructuring years

\begin{tabular}{|l|l|l|l|}
\hline & CRS & VRS & Scale \\
\hline Mean & 0.455 & 0.521 & 0.814 \\
\hline Median & 0.499 & 0.5665 & 0.920 \\
\hline Maximum & 1 & 1 & 1 \\
\hline Minimum & 0.005 & 0.036 & 0.022 \\
\hline Std. Dev. & 0.302 & 0.290 & 0.228 \\
\hline Skewness & 0.104 & 0.007 & -1.392 \\
\hline Kurtosis & 1.628 & 1.661 & 4.152 \\
\hline Observations & 784 & 784 & 784 \\
\hline
\end{tabular}


Table 4 (d) . Descriptive statistics of RRB efficiency: Post-restructuring years

\begin{tabular}{|l|l|l|l|}
\hline & CRS & VRS & Scale \\
\hline Mean & 0.632 & 0.671 & 0.941 \\
\hline Median & 0.650 & 0.682 & 0.969 \\
\hline Maximum & 1.000 & 1.000 & 1.000 \\
\hline Minimum & 0.071 & 0.077 & 0.320 \\
\hline Std. Dev. & 0.183 & 0.188 & 0.078 \\
\hline Skewness & -0.275 & -0.231 & -2.902 \\
\hline Kurtosis & 2.856 & 2.675 & 14.517 \\
\hline Observations & 1764 & 1764 & 1764 \\
\hline
\end{tabular}

Table 5. Test for Equality of Means Between Series

\begin{tabular}{|c|c|c|c|c|}
\hline \multicolumn{2}{|l|}{ Method } & df & Value & Probability \\
\hline \multicolumn{2}{|c|}{ Anova F-test } & $(4,12735)$ & $7.07 \mathrm{E}+08$ & 0.0000 \\
\hline \multicolumn{2}{|c|}{ Welch F-test* } & $(4,6067.89)$ & $1.81 \mathrm{E}+08$ & 0.0000 \\
\hline \multicolumn{5}{|c|}{ *Test allows for unequal cell variances } \\
\hline \multicolumn{3}{|c|}{ Analysis of Variance } & & \\
\hline \multicolumn{2}{|c|}{ Source of Variation } & $\mathrm{df}$ & Sum of Sq. & Mean Sq. \\
\hline \multicolumn{2}{|l|}{ Between } & 4 & $8.12 \mathrm{E}+09$ & $2.03 \mathrm{E}+09$ \\
\hline \multicolumn{2}{|l|}{ Within } & 12735 & 36565.04 & 2.871224 \\
\hline \multicolumn{2}{|l|}{ Total } & 12739 & $8.12 \mathrm{E}+09$ & 637048.7 \\
\hline \multicolumn{5}{|c|}{ Category Statistics } \\
\hline & & & & Std. Err. \\
\hline Variable & Count & Mean & Std. Dev. & of Mean \\
\hline CRS & 2548 & 0.578377 & 0.241341 & 0.004781 \\
\hline VRS & 2548 & 0.625437 & 0.235480 & 0.004665 \\
\hline SCALE & 2548 & 0.902384 & 0.154357 & 0.003058 \\
\hline
\end{tabular}

